\title{
Case Study on Expropriation: Adapazarı-Karasu Railway Project, Turkey
}

\author{
Güler Yalçın ${ }^{1}$ \\ ${ }^{1}$ Osmaniye Korkut Ata Üniversitesi, Mühendislik Fakültesi, Harita Mühendisliği Bölümü \\ e-posta: guleryalcin@osmaniye.edu.tr
}

Geliş Tarihi: 31.01.2017 ; Kabul Tarihi: 03.08.2017

\begin{abstract}
Expropriation is the action of the governmental bodies to obtain immovable when the purpose of public interest is legally recognized. Engineering doesn't include only technical operations and surveying, also legal and social issues such as a land expropriation. In Turkish Expropriation Law, 'urgent expropriation' is an expropriation method which is implemented by State in case of emergency. This paper explains the general expropriation steps through the Expropriation Law in Turkey and one of the applications on the urgent expropriation, Adapazarı-Karasu Railway Connection Line which is 79 km length in SakaryaTurkey, is presented as a sample. Consequently, with this study, the subjects that "the determination of the expropriation value in Turkey is an interdisciplinary issue; the different values for the same property lead to some economic and social problems; sound and reliable data are important for expropriation values; technological developments are needed and should be used for Expropriation Information System with the support of Geographical Information System" are examined. Also it is emphasized that one of the significant points for the expropriation process should be to select the proper land in the environmental view.
\end{abstract}

Anahtar kelimeler Expropriation; Urgent expropriation; Railway.

\section{Kamulaştırma Üzerine Örnek Çalışma: Türkiye, Adapazarı-Karasu Demiryolu Kamulaştırma Projesi)}

\begin{tabular}{cl} 
& Özet \\
\cline { 2 - 3 } & Kamulaştırma, yasal olarak kamu yararı gereği devletin ya da yerel yönetimlerin taşınmaz malları \\
& kazanması eylemi ve yöntemidir. Arazi kamulaştırmalarında mühendislik sadece ölçme ve teknik \\
& işlemlerden ibaret değildir, aynı zamanda yasal ve sosyal konuları da içermektedir. Türkiye'deki \\
Keywords & Kamulaştırma Kanunu'na göre “acele kamulaştırma", devletin acilen kamulaştırma uyguladığı \\
Kamulaştırma; Acele & yöntemdir. Bu çalışma, Kamulaştırma Kanunu doğrultusunda genel kamulaştırma adımlarını \\
kamulaştırma; & açıklamakta, 79 km uzunluğundaki Adapazarı-Karasu Demiryolu Hattı acele kamulaştırma örneği \\
Demiryolu & sunmaktadır. Sonuçta bu çalışmayla “Türkiye'deki kamulaştırma bedelinin belirlenmesinin disiplinler \\
& arası bir çalışma olduğu, bir taşınmaz mala ait farklı değer tespitlerinin sosyal ve ekonomik sorunlara \\
& sebebiyet verdiği, sağlam ve sağlıklı bir kamulaştırma bedeli tespitinde verilerin önemli olduğu, Coğrafi \\
& Bilgi Teknolojileri destekli Kamulaştırma Bilgi Sistemi'nin kurulmasının karar vericilere destek olacağı" \\
& gibi temel konular da irdelenmektedir. Ayrıca kamulaştırma işlemlerinde yer seçerken çevre koruma \\
& bakış açısının da dikkate alınması gerektiği vurgulanmaktadır.
\end{tabular}

(c) Afyon Kocatepe Üniversitesi

\section{Introduction}

While the fears of overpopulation, pollution and exploitation of resources have been arising in the world, it is aimed to preserve the land for future generation with "sustainable development" view because the land is a scarce source. There has been an increasing demand on land and its resources such as food and shelter. Land is the basic source of richness and goods. It is always affected by the forces of demand. In this way land has a supreme importance and "effective administration and 
management" is required to support sustainable development (Mukupa, 2011). "Land administration systems" is related to social, legal, economic and technical framework which land managers and administrations must consider (Int. Ref. 1). There are four main interrelated topics for land administration to achieve sustainable development. These are: land tenure, land value, land use and land development. "Land tenure" is the allocation and security of land rights, legal parcel boundaries' surveys, property transfer/sale/lease, the management and adjudication of doubts and disputes on rights and boundaries. "Land value" is the assessment of the real and tax value of the properties. "Land use" is the administration and management of the land with policies and regulations at different levels such as national, regional and local. "Land development" is to set up basic physical and organizational structures and facilities (e.g., buildings, roads, and power supplies) for a society (Enemark, 2004; Enemark, 2006; Enemark and Seventhal, 1999; Williamson, 2000; Wlliamson et al., 2010). "Land policy" is a set of law rules on land and also a part of the national policy. It is the highest level above land administration and land management in a land hierarchy.

It consists of socio-economic and legal prescriptions on the benefits from the land which are related to economic development, equity and social justice, environmental preservation and sustainable land use (Mukupa, 2011).

Many governments in the world have proposed land policies to facilitate the land conversion and the acquisition of scarce land to achieve socioeconomic goals. The countries implement different ways for lend tenure processes. Land rights in different land tenure regimes determine different techniques and processes for purchase and sale of the land (Phuc et al., 2014). The development of the modern society requires government provision for public benefit, infrastructure and facilities at different government levels such as state, regional or local levels. For the public interest, expropriation is the feasibility of the state or local governments to acquire real property, where the increased benefit for the society is legally recognized. The initial step for expropriation is the acquisition of appropriate land or other kinds of real properties (Sumrada et al., 2013).

Generally, it is seen that the countries that private property ownership is permitted has the state power to acquire compulsorily the private property of the individuals for the public interest or for the public good with the subject to the payment of compensation. This power provides the state with an overriding interest over access, control and management of the real property (Larbi et al., 2004).

"Expropriation of land" discussed in this study is also referred to as eminent domain, compulsory acquisition of land, compulsory purchase and land acquisition. The governments need to provide public facilities and infrastructure that ensure safety and security, health and welfare, social and economic enhancement, and protection and restoration of the natural environment in the view of the sustainable development. To provide such facilities and infrastructure an appropriate land acquisition is required. In some cases when specific land parcels are required, for example, to accommodate the route of a new road, to protect certain areas from flooding, to fulfill the requirements of redistributive land reform legislation, the governments have the power of compulsory acquisition of land (Keith et al., 2008)

Tradition and legislation have important roles on property acquisition for the public benefit. Furthermore, land administration gives the public benefit on real property acquisition (Sumrada et al., 2013). Turkey has a land registry and cadastral system (Cete and Yomralioglu, 2013; Yalcin et al., 2013). Real property is a spatially defined unit of Earth's surface (land unit-parcel). The ownership right on land parcel means the right to possess, use, enjoy and fully dispose of it. The ownership can be restricted by public interests. These rights and restrictions are defined by the legal system. 
Acquisition of property rights by transactions and by inheritance are the most common cases. When the transfer of property rights is caused by a public acquisition based on the agreement or a compulsory purchase the subject is the provision of public authority. It is executed only in two methods: first one is the legislation with a fair compensation; the second one is an appropriate exchange of comparable real properties. In Turkish legal system for the expropriation, 1982 Constitution and The Expropriation Law No.2942 determine the rules of the real property acquisition for the public benefit.

\section{Method: General expropriation procedures in Turkey}

Expropriation is a legal way for the act to take privately owned property by a government or a public corporation to be used for the benefit of the public. In Turkey, the government has the right to take property through expropriation authority. Properties taken through expropriation authorityare often used for public utilities such as highways, railroads, dams, housing...etc. The $46^{\text {th }}$ Article in the third section of The 1982 Constitution titled Social and Economic Rights and Responsibilities focuses on the expropriation. It provides that private property will not be taken for public use without just compensation. Expropriation compensation is paid in cash; however, the payment method for expropriated land values for agricultural reform implementations, large energy, irrigation and housing projects, afforestation, coastal protection and tourism is determined by laws. The law may allow payment in instalments.

"The Expropriation Law No.2942" declares the expropriation procedures. $3^{\text {rd }}$ Article of the law

1"The Expropriation Law No.2942". Official Gazette No: 18215, Publication Date: 08.11.1983. This law has some amendments with laws as following: The Law No.4650 on 24.04.2001, The Law No.5177 on 26.05.2004, The Law No.5999 on 18.06.2010, The Law No.6306 on 16.05.2012.The Law No.6427 on 14.02.2013, The Law No.6459 on 11.04.2013, The LawNo.6487 on 24.05.2013, The accepts $46^{\text {th }}$ Article of the Constitution as the expropriation conditions. Also it adds that the government or the public corporation (administration) cannot start the expropriation procedures without providing adequate funding.

As presented a short workflow diagram in Figure 1, (Akay and Cicek, 2005; Erdin, 2010; Evren, 2012; Tepe, 2009; Turkoglu, 2008; Uzer, 2010) explain all steps of the general expropriation through the expropriation law in their studies:

The first step for the procedures is the decision for the public interest. Public administrations and public corporate bodies decide for the public interest: village elders committee for the benefit of the village, the municipal council for the benefit of the municipality, provincial permanent committee for the benefit of the provincial administration, provincial administrative board for the benefit of the state, the county administrative board for the benefit of many villages and/or municipalities within the same county border, provincial administrative board for the benefit of many villages and/or municipalities within the same city border, council of ministers for the benefit for many public corporations within different cities' borders, council of ministers for the benefit for the State within many cities' borders, board of the directors for the benefit of the public organizations. After the expropriation decision the administration declares it to Land Registration Office to put an annotation onto the title deeds. The property-related changes after this annotation are notified to the administration.

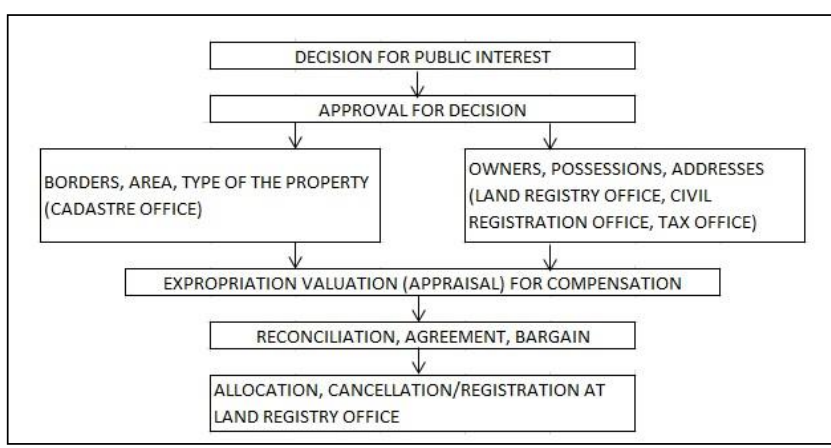

LawNo.6495 on 12.07.2013 and Decision of Constitutional Court on 22.02.2013 
Figure 1: Workflow diagram for expropriation.

The second step is the approval of the public interest decision. Decision approval authority is kaimakam in the counties and governors in the city centers for the decisions of the village elders committees and the municipal councils; governors for the decisions of county administrative boards, provincial permanent boards and provincial administrative boards; minister which they are attached to the control of them for the decisions of public organizations. The public interest decisions provided by Ministries or the Council of Ministers also do not have to be approved.

In the third step the administration makes scaled plans or gets the scaled plans made. These plans represent the borders, area and type of the properties that can be provided by Cadastre Office. Then the owners or users (possessors) of the expropriated properties and their addresses are determined by using the land registrations (Land Registration Office), civil registrations (Civil Registration Office), tax records (Tax Office) and other research documents. The related tax office gives the tax return values or appreciated values within one month to the administration. After the expropriation decision it is notified to the related Land Registration Office and written to the related title deed notebook. At the beginning of this step the administration asks Cadastre Office, Land Registration Office and the courts if there is an ownership dispute.

For the lands which have the completed cadastral and land registry studies, the "purchase style" is the first degree implementation basis in the expropriation process. If the cadastre is not completed the highest authority of the locality is applied for the fact-finding such as the expropriation area, the parcels, the owners/users...etc. For this case detection the authority selects two main and two alternate experts, gets them sworn at The Magistrate's Court and reports these experts to the expropriation administration within 8 days. If the property is not registered in the title deed notebooks, the priority work is to inquire and determine whether if these are public properties or surveyed/registered according to "The Cadastre Law No.3402". In case they are not public properties and they have users instead of owners the experts make investigation, collect the evidences and report the circumstance. This report indicates area of the property, identity of the user, tax registration, start date of the possession and the period, the conditions for acquiring the ownership has taken place. All documents are sent to The Magistrate's Court for valuation and payment method.

The fourth step is the valuation (appraisal). After the public interest decision, the administration creates a Valuation Commission with experts. The valuations are determined in this commission with support documents from related government organizations. In this process the valuation fundamentals in The Expropriation Law No.2942 are used: type, area, all quality and elements which may affect the value of the property and their values, tax statements-if any, valuations that are determined by the official during the expropriation period, income of the properties according the region and the conditions at the expropriation period, value of the sales according to the precedent sales before the expropriation, official unit prices/construction cost accounts/rate of depreciation for buildings and the other objective measures that will be effective determining the price (Yomralioglu et al., 2007).

Also the administration creates The Reconciliation Commission with the people in its body to execute and finalize the procedures of the bargain purchase and barter (exchange) transactions. After the owner accepts the valuation cost it is requested that the owner go to the Land Registration Office on the specified date to waive. Then the expropriation price is paid to the owner. If the reconciliation is not satisfied the courts with the

\footnotetext{
2"The Cadastre Law No.3402”, The Official Gazette No. 19512, Publication Date: 09.07.1987. This law has some amendments with laws as following: The Law No.4576 on 13.06.2000, The Law No.5403 on 03.03.2005, The Law No.5728 on 08.02.2008, The Law No.5831 on 27.01.2009, The Law No.6083 on 10.12.2011, The Law No.6099 on 19.01.2011, The Law No.6302 on 18.05.2012, The Law No.6352 on 05.07.2012, The Law No.6295 on 02.08.2013.
} 
experts determine the expropriation compensation according to the same valuation fundamentals. The court declares region, sheet, island, parcel number, type and area of the property, owners, and the administration that is the responsible for the expropriation...etc. via announcement. The administration pays for the compensation that the court determines to the related bank, notifies it to Land Registration Office. Land Registration Office informs Tax Office.

The expropriation process takes a long time. In some extraordinary circumstances, great, important and urgent investment projects the Urgent Expropriation Decision is applied. Turkish Expropriation Law No.2942 provides the opportunity to dispose of immovable properties for the administration. According to the $27^{\text {th }}$ Article of the Expropriation Law three conditions are reasons for the urgent expropriation: if there is a need for homeland defense, if Council of Ministers decides the urgency for the case, if there is an exceptional circumstances provided by special laws. As in general expropriation process Land Registration, Cadastre and Tax Offices are in the center of the Urgent Expropriation Process. First and initial part of this process is "valuation" step and budget for the compensation, and the other steps are completed later. The administration declares its expropriation decision to the court with the real properties and their related information in a file via Directorship of Accounting ${ }^{3}$ and the court may seize the immoveable properties within 7 days after the processes of valuation according to the valuation fundamentals, experts' valuation, announcement with the owner names and deposit in the bank.

Then the administration calls for the reconciliation with the owners. If the reconciliation on the valuation price is satisfied a new reconciliation report is prepared and signed by the parties. After reconciliation is realized the immovable property is registered on behalf of the administration with the

${ }^{3}$ Directorship of Accounting is a directorship at General Directorate of National Real Estate under Ministry of Finance waiver of the owner within 45 days. If the reconciliation on the valuation price is not satisfied it is written on the report that there is no reconciliation. The administration sues to the Civil Court for expropriation value and the registration of the properties in the name of the administration. The case is declared to the parties by the court.

\section{A case study: Adapazarı-Sakarya Railway in Sakarya, Turkey}

Sakarya is one of 81 provinces in Turkey and located in northeastern of Marmara Region with 16 districts with Adapazarı, Akyazı, Arifiye, Erenler, Ferizli, Geyve, Hendek, Karapürçek, Karasu, Kaynarca, Kocaaali, Pamukova, Sapanca, Serdivan, Söğütlü and Taraklı (Int Ref. 2) (Figure 2). The provincial governorate is set in the central district. The central district usually bears the name of the province. There are only 4 exceptions in Turkey: Sakarya (Adapazarı), Kocaeli (Izmit), Hatay (Antakya) and içel (Mersin). The city of Adapazarı is the capital of the Sakarya province.

Adapazarı-Sakarya gets a lot of migrations from other cities and also many different regions especially from Balkans and Caucasus. It is one of the fast developing, peaceful, calm, Anatolian city in route of İstanbul and Ankara (Int.Ref. 3).

Sakarya has the 22. order in the industry sector of Turkey. There are 739 small and medium businesses such as food products, textile, machinery manufacturing, forest products, metalsteel, petro-chemical, electric, automotive, building and construction. Three industrial zones as Adapazarı, Hendek and Söğütlü are established (Int. Ref. 4).

Sakarya is the center of attraction in the region with geographic advantage and rich economic diversity. It is on the route of Ankara-istanbul roadway, near to the big cities such as Ankara, İstanbul, Kocaeli, Bursa, and has the coast on Black Sea. The industry, commerce and transportation possibilities are in a good situation and also in a 
developing trend. The continuing public investments indicate that the region will continue to grow (Int. Ref. 5). One of these investments is "The Project of Construction of Adapazarı-Karasu Harbours with Industrial Plants and Railway Connection with Station Plants".

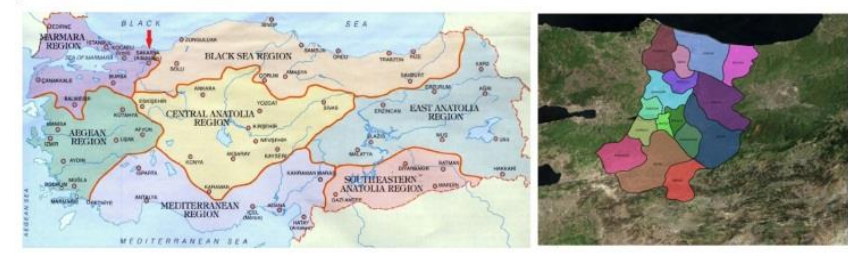

Figure 2: Sakarya City (a) Turkey Map showing SakaryaAdapazarı (Int.Ref. 6), (b) Sakarya with its districts (Int.Ref. 7).

In Turkey Ministry of Transport, Maritime Affairs and Communications (MTMAC) (abolished the Ministry of Transportation) aims "to increase global competitiveness of the country and quality of life for the citizens by providing transport and communications services over the level of contemporary civilizations", also tasks "to provide and monitor transport, information and communications services for all users in a qualified, balanced, safe, environmental friendly, fair and economic manner". The scopes of the activities of the ministry are road transport, maritime transport, civil aviation, railway transport, communications, aeronautics and space technologies, and transport and communications infrastructure. "General Directorate of Infrastructure Investments" (abolished General Directorate of Railways, Harbours and Airports Construction) under Ministry of Transport, Maritime Affairs and Communications (abolished Ministry of Transportation) has been executing its duties with their new names and structures since 1 November 2011 (Int.Ref. 8).

In 2010 an urgent expropriation decision was made and permission was gotten for "The Project of Construction of Adapazarı-Karasu Harbours with Industrial Plants and Railway Connection with
Station Plants" by General Directorate of Railways, Harbours and Airports Construction under Ministry of Transportation according to the Article $27^{\text {th }}$ of The Expropriation Law No.2942. Now this project is carried by General Directorate of Infrastructure Investments (GDII).

\section{Project description, data and methodology}

This project aims to connect two important industrial centers: One is around Zonguldak that has the coal production centers with Ereğli IronSteel Factory and Karabük Iron-Steel Factory, and also their production inputs. The other is Kocaeli that is a major industry production center. It is expected that this project will contribute to the freight transport, and also play a significant role with the railway on passenger transport structure among Black Sea Region, Marmara Region and Central Anatolia Region. Also it is anticipated that it will provide to transfer the products of the ironsteel factories, which are the main input products of Bursa automotive industry, as soon as possible and economically, by the activation of BandırmaBursa-Ayazma-Osmaneli line.

The project extends between Adapazarı and Bartın as a railway project with the length of $285 \mathrm{~km}$, electrification and signalization double line, 4 tunnels, 5 stations and 3 stops, 14 bridges and viaduct (Figure 3a). However, in this study Adapazarı-Karasu Connection Line with 79 km length which is a part of Adapazarı-Bartın Line is investigated and discussed (Figure 3b). 


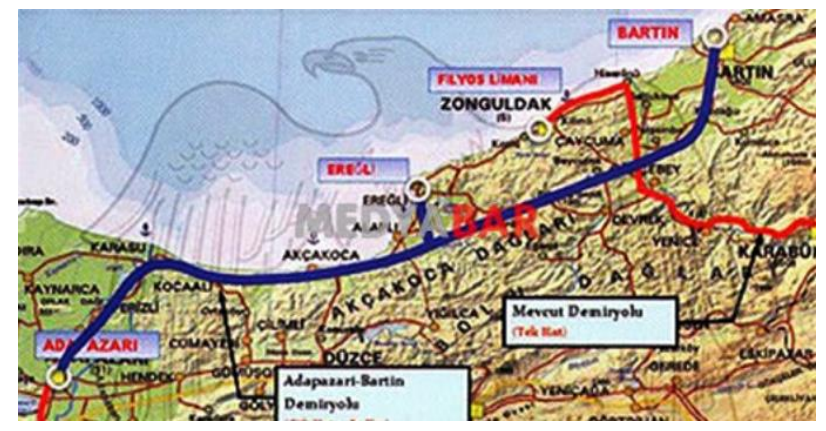

3(a)

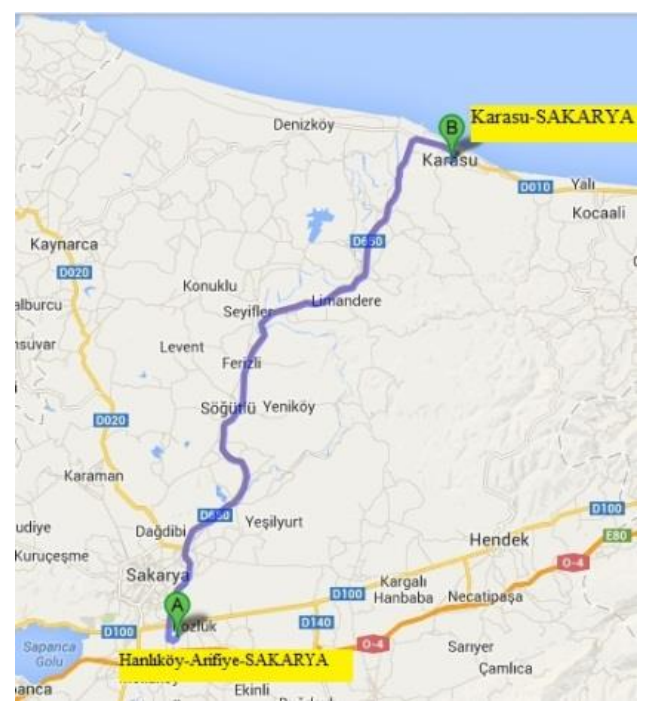

3(b)

Figure 3: a) Adapazarı-Bartın Railway Line b) AdapazarıKarasu Railway Line.

On the route of Adapazarı-Karasu Railway Line, 6 districts and 26 villages/neighbourhoods from Hanlıköy Village-Arifiye District-Sakarya to Karasu (center)-Karasu District-Sakarya have the expropriation procedure. The villages/neighbourhoods with their districts are as following: Arifiye District (Hanlıköy), Adapazarı District (Taşıı, Karaköy, Çökekler, Çelebiler, Kasımlar, Kurtbeyler, Doğancılar, Poyrazlar, Demirbey), Söğütlü District (Beylikkışla, Kurudil, Küçüksöğütlü, Söğütlü), Ferizli District (Ferizli, Sinanoğlu) and Karasu District (Kurumeşe, Limandere, Yuvalıdere, Darıçayırı, Karapınar, Karasu).

In general exploration step;

1. The expropriation plans are prepared and these are approved by Cadastre Office
2. The expropriation files for fixed plant locations in the development plan areas are prepared and these are approved by Cadastre Office.

3. The expropriation files for fixed plant locations outside of the development plan areas are prepared and these are approved by Cadastre Office.

4. The amendments for the development plans which belong to the fixed plant areas are made.

5. The amendments for the development plans in the form of route are made.

In geodetic (surveying) step;

1. The triangulation and polygon points are searched on the field, and also they are established, surveyed and calculated.

2. The link is provided for the county levelling network.

3. The details are measured.

4. The current maps (as-is maps) are created and drawn.

5. Finally, the expropriation route is applied to the field.

In valuation step;

1. The parcels are created according to the cadastre surveying values.

2. The graphic sheets are digitized, if any.

3. The parcels which will be expropriated are determined.

4. The areas are calculated.

5. The cadastral parcels are drawn and the subdivision documents are prepared.

6. The expropriation and easement plans are created and drawn in the scale of cadastral sheet.

7. Forest-permission and easement plans are created and drawn.

8. The allocation plans, easement plans are created and drawn in scale of $1 / 5000$.

9. Valuation

10. The evaluation reports are prepared.

11. The precedent sale information is updated.

12. The addresses of the owners are determined. 
13. The invitation letters and then call letters for the bargain are prepared.

14. Bargaining negotiations are done.

15. The reports for volunteer consensual agreements are prepared.

16. The case files for the objections are prepared.

17. The notifications are made to the owners whom are not obtained to the agreement, are not contributed to the interviews and are not reached.

\section{Results}

In this case study 61 files for the expropriation plans are prepared and approved by Cadastre Office. Then for all these files with owners' information and their addresses, the parcels with the subdivisions are sent to Director of Accounting in Sakarya to forward them to the court. The valuations are determined by the experts who are assigned by the court. These values are reported to GDII Administration. The administration deposits the compensation on behalf of the right holders.

During the expropriation process 15000 parcels are created according to the cadastral survey values, and the registrations for 2000 expropriated parcels are listed with following attributes: province name, district name, cadastral sheet number-island number-parcel number, owner name-surnamefather name, surveying (cadastral) area, portion on the real property, and type of the real property.

For these 2000 parcels the expropriated area is calculated, subdivision documents, valuation and evaluation reports are prepared, and the precedent sale information are updated. To study on the digital environment 50000 graphic plans those, belong to the study area in Cadastre Office are digitized. Figure 4 shows a sample study that indicates the parcels which will be expropriated. Then the calculated area of the parcels between the expropriation borders is used for the compensation.

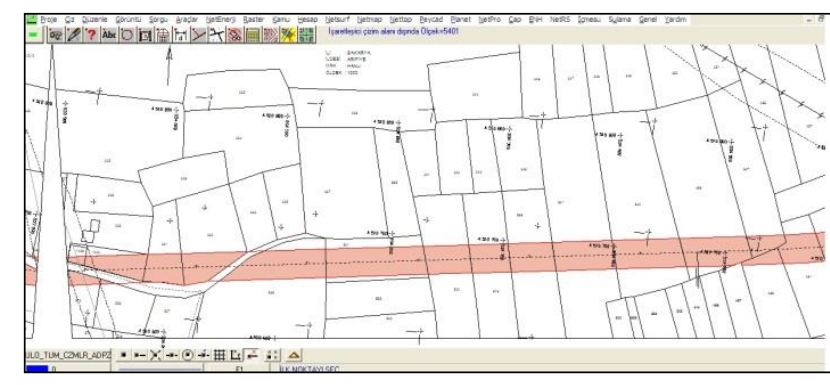

Figure 4: Arifiye-Hanlıköy

Because there are many shareholdings in the real estates, the address determination is done for 3710 owners. This is much more than the parcel numbers expropriated. 500 inheritance letters are regulated for the heirs because of many dead owners in the registrations. 3710 invitation letters and call letters for the compensation bargain are sent to the right holders. After the negotiations 3000 volunteer consensual agreements' reports are prepared.

Table 1 gives an overview numerical evaluation for the expropriation of the real properties. The expropriation case applications for the districts of Arifiye, Erenler and Adapazarı are completed however the case application process has been continuing for other districts. According to the current cases, 394 of 647 parcels in Adapazarı District, 129 of 146 parcels in Erenler and 108 of 121 parcels in Arifiye District have the expropriation cases. It means that nearly $69 \%$ of the real estates raise an objection against expropriation value.

\section{Discussion}

The purpose of this study is to provide an overview for the expropriation of land with a case study. In certain cases, geographical limitations and factors may lead governments to the take of the real properties and their resources from private ownership for a public interest. There is a great variety in the extent of specificity to define public purposes. The list typically include uses such as transportation uses, public buildings, public utilities, public parks, playgrounds, gardens, sports 
facilities and cemeteries and defense purposes (Keith et al., 2008).

Almost every country has specific and distinctive laws and regulations on the expropriation. However International and European Laws generally say that "First, expropriation must be provided for by clear and specific state laws. Second, expropriation is only permitted in order to achieve a public interest. Third, expropriation must be accompanied by adequate, effective and prompt compensation". The rules on the property expropriation are concerned with the laws and the standards (Int. Ref. 9).

In Turkey the expropriation procedure is subject to the normal expropriation procedure with Expropriation Law numbered 2942.

For the expropriation purpose, authorization, procedure, reason and subject of the action must be in line with the law. The key points here are that: Expropriation subject must be an immovable, the compensation payment must be secured, amount in return of the expropriation must be paid.

The expropriation and compensation is an interdisciplinary subject among valuers, surveyors, real estate experts, financiers, urban planners, researchers and decision makers. The rules for compensation depend on the legislation of each country. The main principle in most countries is that the landowner's financial situation remains the same despite the expropriation. Some elements are used to determine the expropriation value for compensation such as type of the property, surface area, the distance to the roads and other settlements, the distance from the City's town center and tourism locations.

In expropriation applications in Turkey there have been problems to find the owners and their addresses. Especially the addresses on the documents at Land Registry Offices are not updated and the information from MERNIS (Merkezi Nüfus İdare Sistemi-Central Population Management System) doesn't give the real addresses. Therefore, the notifications on the expropriation and calls from the courts cannot be received by the owners and the expropriation process is extended, especially it is considered that there are many dead owners and many shareholding heirs.

In Turkey, basically, to determine the real value of the property is the origin of the problem. Many expropriation implementations cause disagreement between the administration (state) and owners. These problems are cases at the courts. Then these can be brought to the European Court of Human Rights (ECHR). They constitute more than $25 \%$ of the cases against The State of Turkey (Yomralioglu et al., 2007). Also 15\% of the decisions about Turkey at ECHR are on the expropriation (Cay and Evren, 2007; Evren, 2012). Some meaningful modifications were made in the Turkish Expropriation Law to reduce the objections to expropriation and land prices in different dates. However, some more needs should be provided for an effective land assessment procedure in expropriation works in Turkey. As seen in this case study nearly $69 \%$ of the properties' owners in only 3 districts of Sakarya has an objection to the land values and the process to sue for the land values for the other districts have been going on.

The expropriation process takes a long time in Turkey. The rightful owner wants and needs to get the payment immediately or as soon as possible. In the urgent expropriation process as in this case study, the administration makes the payment in personal bank account of the rightful owner before acquiring the land. Valuation claims are heard and settled before the ownership transfers are made. Any land/assets can't be expropriated prior to the payment. In case there is no agreement between the administration and the owner on the expropriation value, the administration goes to the court for the re-assessment of the property, however the first payment is done on behalf of the owner.

At each step of the expropriation sound and reliable data are needed and the technological 
developments should be used. For a sound expropriation the data should be digital and updated. Geographic Information Technologies provide faster procedures, payments and decisions, and also fairer expropriation policy. The local authorities, which have Geographic Information System (GIS) applications, have the most of the current maps (as-is maps), cadastral maps and ownership data in the digital environment. The technology and its network increase the accuracy of decision-making, prevent duplication of the works, and enable the use of the resources. To obtain the ownership and address data took too much time, especially inter-institutional correspondence. In this scope the interoperability among the institutions should be improved in the technological environment. As a result of the technological studies The Expropriation Information System should be established with the project data and evaluation criteria.

Property valuation plays an important role in the economic and social life of a human. The determination different values for the same property leads to some economic and social problems: For example, tax value, expropriation value, purchase value, sale value. Also the valuations should be objective, correct and accredited considering the facts of quality, environment and usage conditions. An information system is an effective solution that will provide a help to a valuation expert to obtain social, legal and technical data on a real property.

Collection of variable information takes a long time and high costs. However, sometimes the same information is collected by different experts. It is needed to compose a safety database system in real estate market. In addition, Real Estate Valuation Maps should be developed by using GIS technologies.

One of the significant points for the expropriation process is to select the proper land in the environmental view and not to limit the public benefit in another way. The past examples show that the fertile soils, sea coasts, relaxation areas, resort (countryside) areas are expropriated by the public institutions such as in Trabzon and Samsun cities in Turkey (Akyol and Yomralioglu, 1992). In another point of view of Turkish Expropriation Law urgent expropriation decision is applied in case homeland defense is concerned, additionally Ministers' decisions for urgent cases and special laws. However, in recent years Council of Ministers has been approving the urgent expropriation for decisions of Municipalities and public institutions in different fields such as urban transformation/renewal/regeneration, electric lines, hydroelectric-power plants...etc.

\section{Conclusion}

In Turkey land and human activities are very high, especially with the support of land registry and cadastre system. According to the Turkish 1982 Constitution every citizen has a property rights however these private rights can only be restricted when a public interest is occurred. The Turkish Expropriation Law arranges the public land requirements. In this study the legal structure of the expropriation in Turkey is identified, and it is exampled on a railway in Sakarya.

The expropriation process has many different disciplines such as technical study, social sciences, law, politics, economics and communication. Enacted laws and regulations are for the public interest and citizen-focused but still there are unsatisfied people and they prefer to sue.

To ensure a strong public interest "geographic information technologies" is a good choice and solution for long-term realistic plans for institutions, experts and courts.

Expropriation is one of the ways of dealing with land and land policy. Also the expropriations can act as a strong instrument supporting the protection of the environment if the legal implication of the expropriations is considered.

To ensure a strong public interest "geographic information technologies" is a good choice and 
solution for long-term realistic plans for institutions, experts and courts.

Expropriation is one of the ways of dealing with land and land policy. Also the expropriations can act as a strong instrument supporting the protection of the environment if the legal implication of the expropriations is considered.

\section{Acknowledgements}

Author would like to thank her colleagues, Hakan BOZKURT (MSc.Mapping Engineer, Head of Expropriation Department), Naci ATES (Mapping Engineer, Mapping Branch Manager), Cengiz ALTAN (Mapping Engineer), Yasemin OZDEMIR (Mapping Technician) and all other surveyors at General Directorate of Infrastructure Investments for their helps and supports.

\section{References}

Akay, Y. and Cicek, Y., 2005. Uygulamalı Kamulaştırma Tekniği. Harita ve Kadastro Mühendisleri Odası Yayınları, Ankara, Türkiye.

Akyol, N., Yomralioglu T. and Uzun, B., 1992. "Türkiye'de ve gelişmiş ülkelerde kamulaştırma çalışmaları". Karadeniz Teknik Üniversitesi Jeodezi ve Fotogrametri Mühendisliği Bölümü İmar Planlarının Uygulanması Semineri, Trabzon, 1992.

Cay, T. and Evren, N. 2007. "Kamulaştırma uygulamalarında uzlaşma başarımı". 11. Türkiye Harita Bilimsel ve Teknik Kurultayı, Ankara, 2-6 April 2007.

Cete, M. and Yomralioglu, T. 2013. Re-engineering of Turkish land administration. Survey Review, 45(330), 197-205.

Enemark, S. 2004. "Building land information policies". UN, FIG, PC IDEA Inter-regional Special Forum on The Building of Land Information Policies in the Americas, Aguascalientes, Mexico 26-27 October 2004.

Enemark, S. and Sevantal, H. 1999. "Cadastres, land information systems and planning- is decentralization a significant key to sustainable development?" Technical Papers of UN-FIG International Conference on Land Tenure and Cadastral Infrastructures for Sustainable
Development, Melborne, Australia, 24-27 October 1999.

Enemark, S. 2006. "People, politics and placesresponding to the millennium development goals". Land Policies and Legal Empowerment of the Poor International Workshop. World Bank, Washington, 2-3 November 2006.

Erdin, E.O. 2010. Kamulaştırma bilgi sisteminin oluşturulması: Musabeyli Barajı örneği. Yüksek Lisans Tezi, Erciyes Üniversitesi, Fen Bilimleri Enstitüsü, Kayseri.

Evren, N. 2012. Türkiye'de kamulaştırma çalışmaları için alternatif yaklaşımlar. Doktora Tezi, Selçuk Üniversitesi Fen Bilimleri Enstitüsü,Konya.

Keith, S., McAuslan, P., Knight, R., Lindsay, P.M.F. and Palmer, D. 2008. Compulsory compensation. Food and agriculture organization of the United Nations". Rome, Italy.

Larbi, W.O., Antwi, A. and Olomolaiye, P. 2004. Compulsory land acquisition in ghana-policy and praxis. Land Use Policy,21, 115-127, 2004. doi:10.1016/j.landusepol.2003.09.004.

Mukupa, W. 2011. Land administration to support sustainable development. FIG Working Week 2011, Bridging the Gap Between Cultures, Marrakech, Morocco, 18-22 May 2011.

Phuc, N.Q., Westen, A.C.M., and Zommers van, A. 2014. Agricultural land for urban development: the process of land conversion in central Vietnam". Habitat International, 41, 1-7, 2014.

Sumrada, R., Ferlan, M., Lisec, A. 2013. Acquisation and expropriation of real property for the public benefit in Slovenia". Land Use Policy,32, 14-22, 2013. doi: 10.1016/i.landusepol.2012.10.004.

Williamson, I.P. 2000. Best practices for land administration systems in developing countries. International Conference on Land Policy Reform, Jakarta, 25-27, 2000.

Williamson, I., Enemark, S., Wallace, J. and Rajabard, A. 2010. Land administration for sustainable development. FIG International Congress, Sydney, Australia, 11-16 April 2010.

Tepe, S. 2009. Kamulaştırma ve mülkiyet ilişkisinin irdelenmesi üzerine bir araştırma. Yüksek Lisans Tezi, Selçuk Üniversitesi Fen Bilimleri Enstitüsü,Konya.

Turkoglu, I. 2008. Petrol arama - iletim faaliyetlerinde kamulaştırma ve problemleri. 
Yüksek Lisans Tezi, Karadeniz Teknik Üniversitesi, Fen Bilimleri Enstitüsü, Trabzon.

Uzer, Z.Y. 2010. Kamulaştırma uygulamalarında hazine arazilerinden yararlanma ve siT alanlarına ilişkin uygulamaların incelenmesi. Yüksek Lisans Tezi, Karadeniz Teknik Üniversitesi Fen Bilimleri Enstitüsü, Trabzon.

Yalcin, G., Bol, A. and Eski, C. 2013. Studies on renovation of cadastral sheets for urbanization. Survey Review,45(329), 141-154, 2013. doi: 10.1179/1752270612Y.0000000023.

Yomralioglu, T., Uzun, B., and Nisanci, R. 2007. Land valuation issues of expropriation applications in Turkey. FIG Commission 9, Seminar on Compulsory Purchase and Compensation in Land Acquisition and Takings, Helsinki, Finland, September 6-8, 2007.

\section{Internet References}

http://www.unece.org/env/hs/wpla/docs/guide lines/lag.html., (30.05.2011). United Nations Economic Commission for Europe Land Administration Guidelines, Newyork and Geneva", 1996.

http://www.sakaryakultur.gov.tr/e-kitap/rehber/., (15.08.2013). Sakarya Governorship. Guideline for Sakarya.

http://www.sakarya.bel.tr/sakarya.php?id=11\&uk= 13\&ak=75\&uk2=11.,(15.08.2013). Sakarya Municipality. Short Information about Adapazarı-SAKARYA.

http://www.sakarya.bel.tr/pictures/upload/plan.pd f., (19.05.2013). Sakarya Municipality. 20102014 Strategic Plan.

http://www.marka.org.tr/uploads//Files/RegionalP lan/EastMarmara2014-2023RegionalPlan.pdf., (31.01.2017). East Marmara Development Agency. East Marmara Region Plan 2014-2023, 2013.

http://www.gototurkey.co.uk/destinations/., (25.07.2013). Turkish Culture and Tourism Office.

http://www.marka.org.tr/sayfa/1/28/sakarya., (13.09.2013).East Marmara Development Agency. Sakarya Geographic Location.

http://www.dlh.gov.tr/., MTMAC(Ministry of Transport, Maritime Affairs and Communications, General Directorate of Infrastructure Investments) website. http://www.mreza-mira.net/wpcontent/uploads/Expropriation-in-Europe-Jan2013.pdf., (20.09.2013). Legal Memorandum. Land Expropriation in Europe. 
Table 1. An overview numerical evaluation for the expropriation of the real properties.

AN OVERVIEW NUMERICAL EVALUATION FOR THE REAL PROPERTIES EXPROPRIATED

\begin{tabular}{|c|c|c|c|c|c|c|c|c|c|c|c|c|c|c|c|c|c|c|c|}
\hline \multirow{3}{*}{$\begin{array}{l}\text { NAME OF } \\
\text { DISTRICT }\end{array}$} & \multirow{3}{*}{$\begin{array}{l}\text { NAME OF VILLAGE/ } \\
\text { NEIGHBOURHOOD }\end{array}$} & \multirow{3}{*}{\begin{tabular}{|c|} 
TOTAL \\
NUMBER OF \\
THE PARCELS
\end{tabular}} & \multirow{3}{*}{$\begin{array}{l}\text { THE NUMBER OF } \\
\text { PARCELS FOR THE } \\
\text { VALUATION } \\
\text { CASES }\end{array}$} & \multirow{2}{*}{\multicolumn{3}{|c|}{ INDIVIDUAL (PRIVATE) PERSON }} & \multirow{2}{*}{\multicolumn{8}{|c|}{ LEGAL ENTITY }} & \multirow{2}{*}{\multicolumn{2}{|c|}{ FOREST }} & \multirow{2}{*}{\multicolumn{2}{|c|}{ TREASURE OF FINANCE }} & \multirow{3}{*}{$\begin{array}{l}\text { The net length of } \\
\text { the railway taht } \\
\text { will be } \\
\text { expropriated (m. }\end{array}$} \\
\hline & & & & & & & & & & & & & out of $r$ & gistration & & & & & \\
\hline & & & & $\begin{array}{l}\text { number of } \\
\text { parcels }\end{array}$ & $\begin{array}{l}\text { number of } \\
\text { owners }\end{array}$ & area $(m 2)$ & $\begin{array}{l}\text { number } \\
\text { of parcels }\end{array}$ & area (m2) & \begin{tabular}{|l} 
number \\
of parcels
\end{tabular} & $\begin{array}{l}\text { sarea } \\
\text { (m2) }\end{array}$ & $\begin{array}{l}\text { number } \\
\text { of parcels }\end{array}$ & area (m2) & $\begin{array}{l}\text { number of } \\
\text { parcels }\end{array}$ & area (m2) & $\begin{array}{l}\begin{array}{l}\text { number of } \\
\text { parcels }\end{array} \\
\end{array}$ & farea (m2) & $\begin{array}{l}\text { number of } \\
\text { parcels }\end{array}$ & area (m2) & \\
\hline \multirow{8}{*}{ KARASU } & KARASU (CENTER) & \multirow{8}{*}{408} & $\mid$ & 121 & 402 & 200215.30 & 5 & 2046.92 & 0 & 0 & 1 & 1288.20 & 1 & 693.67 & 7 & 122499.82 & 18 & 28097.30 & 5185.10 \\
\hline & KARAPINAR & & * & 37 & 177 & 117447.84 & 0 & 0 & 0 & 0 & 0 & 0 & 0 & 0 & 0 & 0 & 0 & 0 & 2035.99 \\
\hline & DARIÇAYIRI & & * & 7 & 11 & 8255.28 & 7 & 224619.46 & 0 & 0 & 0 & 0 & 0 & 0 & 0 & 0 & 0 & 0 & 3867.39 \\
\hline & TEPETARLA & & * & 1 & 8 & 11340.93 & 2 & 48179.27 & 0 & 0 & 0 & 0 & 0 & 0 & 0 & 0 & 4 & 4685.10 & 1066.55 \\
\hline & YUVALIDERE & & * & 55 & 163 & 142129.66 & 0 & 0 & 0 & 0 & 0 & 0 & 0 & 0 & 2 & 11764.75 & 33 & 68742.27 & 3399.79 \\
\hline & \begin{tabular}{|l|l|} 
LiMANDERE \\
\end{tabular} & & * & 29 & 75 & 85295.17 & 1 & 1554.44 & 0 & 0 & 0 & 0 & 0 & 0 & 0 & 0 & 50 & 126305.99 & 2835.69 \\
\hline & KARANLIKDERE & & * & 0 & 0 & 0 & 0 & 0 & 0 & 0 & 0 & 0 & 0 & 0 & 0 & 0 & 14 & 69190.85 & 939.52 \\
\hline & KURUMEȘE & & $*$ & 4 & 4 & 12178.40 & 0 & 0 & 0 & 0 & 0 & 0 & 0 & 0 & 3 & 83035.90 & 7 & 4314.60 & 1694.07 \\
\hline \multirow{2}{*}{ FERizLi } & FERIZLi (CENTER) & \multirow{2}{*}{338} & * & 303 & 630 & 305170.71 & 0 & 0 & 0 & 0 & 0 & 0 & 2 & 35657.30 & 0 & 0 & 1 & 1879.40 & 6119.39 \\
\hline & SINANOĞLU & & * & 80 & 202 & 205148.25 & 0 & 0 & 0 & 0 & 0 & 0 & 0 & 0 & 3 & 80351.64 & 12 & 22966.27 & 4881.43 \\
\hline \multirow{4}{*}{ SÖĞÜTLÜ } & SÖĞÜTLÜ (CENTER) & \multirow{4}{*}{340} & * & 215 & 536 & 304964.02 & 1 & 344.10 & 0 & 0 & 0 & 0 & 0 & 0 & 0 & 0 & 0 & 0 & 4116.73 \\
\hline & KÜÇÜKSÖĞÜTLÜ & & * & 61 & 113 & 119014.55 & 0 & 0 & 0 & 0 & 0 & 0 & 1 & 5987.88 & 3 & 5018.09 & 1 & 2965.80 & 1688.85 \\
\hline & KURUDiL & & * & 48 & 81 & 96496.75 & 0 & 0 & 0 & 0 & 1 & 3254.31 & 2 & 6645.21 & 0 & 0 & 0 & 0 & 1846.01 \\
\hline & BEYLiKKIŞLA & & * & 6 & 6 & 20598.36 & 1 & 8170.35 & 0 & 0 & 1 & 12429.16 & 0 & 0 & 0 & 0 & 1 & 443.86 & 801.77 \\
\hline \multirow{10}{*}{ ADAPAZARI } & DEMiRBEY & \multirow{10}{*}{647} & 17 & 33 & 79 & 60331.29 & 0 & 0 & 0 & 0 & 0 & 0 & 0 & 0 & 0 & 0 & 0 & 0 & 1061.41 \\
\hline & \begin{tabular}{|l|} 
POYRAZLAR \\
\end{tabular} & & 25 & 39 & 61 & 44042.16 & 0 & 0 & 0 & 0 & 0 & 0 & 0 & 0 & 0 & 0 & 4 & 764.76 & 636.61 \\
\hline & DOĞANCILAR & & 67 & 208 & 475 & 214785.65 & 1 & 557.95 & 0 & 0 & 0 & 0 & 0 & 0 & 3 & 6174.32 & 5 & 714.56 & 1305.42 \\
\hline & KURTBEYLER & & \multirow{2}{*}{29} & 133 & 213 & 173847.80 & 0 & 0 & 0 & 0 & 0 & 0 & 0 & 0 & 0 & 0 & 3 & 735.28 & 2749.73 \\
\hline & KURTBEYLER & & & 46 & 80 & 54209.46 & 0 & 0 & 0 & 0 & 0 & 0 & 0 & 0 & 0 & 0 & 0 & 0 & 1067.13 \\
\hline & KASIMLAR & & 42 & 71 & 104 & 120732.52 & 0 & 0 & 0 & 0 & 0 & 0 & 0 & 0 & 0 & 0 & 0 & 0 & 1454.46 \\
\hline & \begin{tabular}{|l|} 
ÇELEBiLEER \\
\end{tabular} & & 21 & 38 & 71 & 44884.97 & 0 & 0 & 0 & 0 & 2 & 15414.36 & 0 & 0 & 0 & 0 & 0 & 0 & 1046.72 \\
\hline & $\begin{array}{l}\text { RÜSTEMLER } \\
\end{array}$ & & 44 & 64 & 126 & 76115.50 & 0 & 0 & 0 & 0 & 0 & 0 & 0 & 0 & 0 & 0 & 1 & 3826.38 & 1151.18 \\
\hline & çÖKEKLER-KARAKÖY & & 31 & 39 & 62 & 40495.77 & 1 & 1653.88 & 0 & 0 & 6 & 23426.86 & 2 & 36560.75 & 0 & 0 & 6 & 2944.17 & 13232.14 \\
\hline & TAŞLIK & & 118 & 167 & 300 & 188681.11 & 1 & 4.00 & 0 & 0 & 1 & 45994.20 & 1 & 34356.30 & 0 & 0 & 0 & 0 & 3947.12 \\
\hline \multirow{2}{*}{ ERENLER } & PIRAHMETLER & \multirow{2}{*}{146} & \multirow[b]{2}{*}{129} & \multirow[b]{2}{*}{128} & \multirow[b]{2}{*}{194} & 117695.98 & \multirow[b]{2}{*}{15} & 9205.23 & 0 & 0 & 0 & 0 & 0 & 0 & 0 & 0 & 0 & 0 & \\
\hline & KOZLUK & & & & & 59077.78 & & 12227.09 & 0 & 0 & 1 & 21013.02 & 0 & 0 & 0 & 0 & 0 & 0 & 3378.85 \\
\hline ARIFIYE & HANLI KÖY & 121 & 103 & 107 & 263 & 105980.84 & 11 & 28441.93 & 0 & 0 & 0 & 0 & 0 & 0 & 0 & 0 & 5 & 26616.86 & 4251.34 \\
\hline
\end{tabular}

